This article is a preprint, i.e. it is the author's version of the manuscript, prior to input from peer-reviewing. Hence there may be considerable differences compared to the final version of the article.

The final version of the article is published in:

Applied Energy 2014;113:1924-1932.

DOI: 10.1016/j.apenergy.2013.06.016

The final version can be found here:

http://www.sciencedirect.com/science/article/pii/S0306261913005230 


\title{
Combined oxides as oxygen carrier material for chemical-looping with oxygen uncoupling
}

\author{
Magnus Rydén $^{1}{ }^{*}$, Henrik Leion ${ }^{1}$, Tobias Mattisson ${ }^{1}$, Anders Lyngfelt ${ }^{1}$ \\ ${ }^{1}$ Chalmers University of Technology, S-412 96, Göteborg, Sweden \\ *Corresponding Author, magnus.ryden@chalmers.se
}

\begin{abstract}
Oxygen-carrier materials for chemical-looping with oxygen uncoupling (CLOU) must be capable to take up and release gas-phase $\mathrm{O}_{2}$ at conditions relevant for generation of heat and power. In principle, the capability of a certain material to do so is determined by its thermodynamic properties. This paper provides an overview of the possibility to design feasible oxygen carrier materials from combined oxides, i.e. oxides with crystal structures that include several different cations. Relevant literature is reviewed and the thermodynamic properties and key characteristics of a few selected combined oxide systems are calculated and compared to experimental data. The general challenges and opportunities of the combined oxide concept are discussed. The focus is on materials with manganese as one of its components and the following families of compounds and solid solutions have been considered: $\left(\mathrm{Mn}_{\mathrm{y}} \mathrm{Fe}_{1-\mathrm{y}}\right) \mathrm{O}_{\mathrm{x}},\left(\mathrm{Mn}_{\mathrm{y}} \mathrm{Si}_{1-\mathrm{y}}\right) \mathrm{O}_{\mathrm{x}}$, $\mathrm{CaMnO}_{3-\delta},\left(\mathrm{Ni}_{\mathrm{y}} \mathrm{Mn}_{1-\mathrm{y}}\right) \mathrm{O}_{\mathrm{x}},\left(\mathrm{Mn}_{\mathrm{y}} \mathrm{Cu}_{1-\mathrm{y}}\right) \mathrm{O}_{\mathrm{x}}$ and $\left(\mathrm{Mn}_{\mathrm{y}} \mathrm{Mg}_{1-\mathrm{y}}\right) \mathrm{O}_{\mathrm{x}}$.
\end{abstract}

Chemical-looping with oxygen uncoupling

Chemical-looping combustion (CLC) is an innovative method to oxidize fuels with inherent $\mathrm{CO}_{2}$ sequestration. Two separate reactors are used, one air reactor (AR) and one fuel reactor (FR). A solid oxygen carrier $\left(\mathrm{MeO}_{\mathrm{x}} / \mathrm{MeO}_{\mathrm{x}-1}\right)$ performs the task of transporting oxygen between the reactors. Direct contact between fuel and air is avoided, see Figure 1.

The oxygen carrier circulates between the two reactors. In the fuel reactor, it is reduced by the fuel, which in turn is oxidized to $\mathrm{CO}_{2}$ and $\mathrm{H}_{2} \mathrm{O}$ according to reaction (1). In the air reactor, it is oxidized to its initial state with $\mathrm{O}_{2}$ from the air according to reaction (2). Combining reaction (1) and reaction (2) yields reaction (3), which is complete combustion of the fuel with $\mathrm{O}_{2}$. 
$\mathrm{C}_{\mathrm{n}} \mathrm{H}_{\mathrm{m}}+(2 \mathrm{n}+1 / 2 \mathrm{~m}) \mathrm{MeO}_{\mathrm{x}} \rightarrow \mathrm{nCO} \mathrm{CO}_{2}+(1 / 2 \mathrm{~m}) \mathrm{H}_{2} \mathrm{O}+(2 \mathrm{n}+1 / 2 \mathrm{~m}) \mathrm{MeO}_{\mathrm{x}-1}$

$\mathrm{MeO}_{1-\mathrm{x}}+1 / 2 \mathrm{O}_{2} \rightarrow \mathrm{MeO}_{\mathrm{x}}$

$\mathrm{C}_{\mathrm{n}} \mathrm{H}_{\mathrm{m}}+(\mathrm{n}+1 / 4 \mathrm{~m}) \mathrm{O}_{2} \rightarrow \mathrm{nCO}_{2}+(1 / 2 \mathrm{~m}) \mathrm{H}_{2} \mathrm{O}$

Chemical-looping combustion has several attractive features. The gas from the fuel reactor consists essentially of $\mathrm{CO}_{2}$ and $\mathrm{H}_{2} \mathrm{O}$ so condensation of steam to liquid water is all that is needed to obtain almost pure $\mathrm{CO}_{2}$ for sequestration. A feasible design is to use a circulating fluidized bed reactor with oxygen-carrier particles as bed material, which is straightforward and available technology. Commonly proposed oxygen carrier materials include transition metal oxides such as $\mathrm{NiO}, \mathrm{Fe}_{2} \mathrm{O}_{3}, \mathrm{CuO}$ or $\mathrm{Mn}_{3} \mathrm{O}_{4}$. The progress within the area of has been reviewed recently by Adanez et al. [1] and Lyngfelt [2].

In reaction (1), it was assumed that the fuel is in gas phase and that it reacts with the oxygen carrier in a gas-solid-reaction. However, with some oxygen carrier materials gas-phase $\mathrm{O}_{2}$ can be released directly in the fuel reactor according to reaction (4).

$\mathrm{MeO}_{\mathrm{x}} \leftrightarrow \mathrm{MeO}_{1-\mathrm{x}}+1 / 2 \mathrm{O}_{2}$

$\mathrm{O}_{2}$ will be released until equilibrium for reaction (4) is obtained. If there is a fuel present it will react directly with released $\mathrm{O}_{2}$ according to reaction (3), which will facilitate further $\mathrm{O}_{2}$ release until all available fuel is consumed. The reduced oxygen carrier can then be recirculated to the air reactor where it is reoxidized according to reaction (2).

This reaction scheme described above is referred to as chemical-looping with oxygen uncoupling (CLOU), see Mattisson et al. [3]. The sum of reactions is identical to the one for chemical-looping combustion, but the mechanism by which the fuel is oxidized is different. In ordinary chemical-looping combustion, the oxidation of fuel takes place mainly via gas-solids reactions. So if the fuel is a solid such as coal, it has to be gasified in order to be able to react with the solid oxygen carrier. By contrast, in chemical-looping with oxygen uncoupling, the oxidation of the fuel can proceed by direct combustion. Leion et al. [4] have shown that oxidation of coke can be orders of magnitude faster using this reaction scheme compared to a conventional chemical-looping combustion process which relies on char gasification.

\subsection{Aim of this study}

The aim of this study is to provide an overview of the possibility to design oxygen carrier materials from combined oxides, i.e. oxides with structures that include several different cations. 


\section{Oxygen carriers for chemical-looping with oxygen uncoupling}

The central requirement for an oxygen-carrier material for chemical-looping with oxygen uncoupling is that it should be capable of taking up and releasing gas-phase $\mathrm{O}_{2}$ at conditions relevant for char combustion. This capability is dictated by the equilibrium $\mathrm{O}_{2}$ partial pressure $\left(p_{O 2}\right)$ for reaction (4), which is different for different materials and also a function of parameters such as temperature and pressure.

In a real-world facility for power generation with a conventional Clausius-Rankine cycle, the $\mathrm{O}_{2}$ concentration in the outlet of the air reactor would preferably be low. High excess air reduces the efficiency of the plant and increases costs. In this work it is assumed that the highest acceptable $\mathrm{O}_{2}$ concentration in the gas from the air reactor is $5 \%$, i.e. an excess air ratio of $20 \%$, which is comparable to what is used in circulating fluidized bed boilers. This means that the equilibrium $\mathrm{O}_{2}$ partial pressure for reaction (4) should not be higher than $5 \%$ at the desired air reactor temperature, else reoxidation will be impossible. Hence calculating this temperature $\left(T_{e q, P O 2=5 \%}\right)$ provides the maximum air reactor temperature for a certain oxygen carrier.

As for the fuel reactor, high temperature equals a higher partial pressure of $\mathrm{O}_{2}$ according to reaction (4) and faster overall reaction kinetics. As will be explained below, oxygen carriers for chemical-looping with oxygen uncoupling typically gives slightly exothermic reactions with fuel in the fuel reactor. It seems reasonable to assume that heat will be extracted in the air reactor to control the temperature here, while the fuel reactor will be allowed operate at similar or slightly higher temperature.

Depending on solids circulation and solids inventory, the $\mathrm{O}_{2}$ release could well be higher than what is consumed by the fuel. This would then lead to the presence of oxygen in the gas from the fuel reactor. Thus, it can be assumed that operation with oxygen carriers that release oxygen will need proper control systems to avoid either excess of oxygen or unconverted fuel gas.

Since the reactions in the fuel reactor typically are exothermic, high solids circulation should not be necessary to maintain the overall heat balance. Instead, the minimum solids circulation will be determined by the oxygen carrier capacity $\left(R_{0}\right)$ which is defined in equation $(5)$, in which $m_{o x}$ is the weight of the fully oxidized sample and $m_{\text {red }}$ is the weight of the fully reduced.

$R_{0}=\left(m_{o x}-m_{r e d}\right) / m_{o x}$ 
Below is an overview over some binary and ternary oxide systems which have been identified as promising for the proposed application. All data and phase diagrams have either been calculated with the software FactSage 6.1 using the FToxid database, or in some case been taken from identified sources. The results are summarized in section 3 below.

\subsection{Monometallic oxygen carriers}

Although not the focus of this study, it should be mentioned that there are monometallic systems which could be feasible for the discussed application. $\mathrm{CuO}$ is commonly proposed and has been shown to release $\mathrm{O}_{2}$ rapidly via reaction (6) at temperatures in the range of 850$950^{\circ} \mathrm{C}$, see for example Leion et al. [4], Gayán et al. [5], Eyring et al. [6] and Arjmand et al. [7]. Further, $\mathrm{Mn}_{2} \mathrm{O}_{3}$ could release $\mathrm{O}_{2}$ via reaction (7), but reoxidation is restricted to low temperatures where the rate of reaction appears to be too slow to be practically applicable [3]. Finally, $\mathrm{Co}_{3} \mathrm{O}_{4}$ could release $\mathrm{O}_{2}$ via reaction (8), but this system looks unattractive due to unfavourable cost, health and environmental characteristics [3]. The equilibrium $\mathrm{O}_{2}$ partial pressure for reactions (6-8) can be found in Figure 2.

$4 \mathrm{CuO} \leftrightarrow 2 \mathrm{Cu}_{2} \mathrm{O}+\mathrm{O}_{2}$

$6 \mathrm{Mn}_{2} \mathrm{O}_{3} \leftrightarrow 4 \mathrm{Mn}_{3} \mathrm{O}_{4}+\mathrm{O}_{2}$

$2 \mathrm{Co}_{3} \mathrm{O}_{4} \leftrightarrow 6 \mathrm{CoO}+\mathrm{O}_{2}$

\section{$2.2\left(\mathrm{Mn}_{\mathrm{y}} \mathrm{Fe}_{1-\mathrm{y}}\right) \mathrm{O}_{\mathrm{x}}$ combined oxides}

The ternary system Mn-Fe-O has properties which make it exceptionally interesting for oxygen carrier applications. In fact, such oxides have already been proven to be capable of releasing considerable amounts of gas phase $\mathrm{O}_{2}$, see Azimi et al. [8, 9, 10], Rydén et al. [11] and Shulman et al. [12]. This family of materials is believed to be resistant towards fuel impurities such as sulfur and could also be manufactured from cheap and relatively harmless raw materials.

A binary phase diagram of the $\left(\mathrm{Mn}_{\mathrm{y}} \mathrm{Fe}_{1-\mathrm{y}}\right) \mathrm{O}_{\mathrm{x}}$ system is shown in Figure 3. It can be seen that hematite $\left(\mathrm{Fe}_{2} \mathrm{O}_{3}\right)$ and bixbyite $\left(\mathrm{Mn}_{\mathrm{y}} \mathrm{Fe}_{1-\mathrm{y}}\right)_{2} \mathrm{O}_{3}$ are favored at lower temperature, while spinel phases $\left(\mathrm{Mn}_{\mathrm{y}} \mathrm{Fe}_{1-\mathrm{y}}\right)_{3} \mathrm{O}_{4}$ are favored at higher temperature. At intermediate temperatures there is a two-phase area in which both forms coexist. The reaction of interest to chemical-looping with oxygen uncoupling is transition between bixbyite and spinel via reaction (9).

$6(\mathrm{Mn}, \mathrm{Fe})_{2} \mathrm{O}_{3} \leftrightarrow 4(\mathrm{Mn}, \mathrm{Fe})_{3} \mathrm{O}_{4}+\mathrm{O}_{2}$ 
In Figure 3, it can be seen that if the surroundings has an $\mathrm{O}_{2}$ partial pressure of $0.05 \mathrm{~atm}$, reaction (9) goes to the right at temperatures over $\approx 1330^{\circ} \mathrm{C}$ for pure $\mathrm{Fe}_{2} \mathrm{O}_{3}$. The corresponding temperature for pure $\mathrm{Mn}_{2} \mathrm{O}_{3}$ is $\approx 800^{\circ} \mathrm{C}$. For mixtures of the two, $\mathrm{O}_{2}$ release happen at intermediate temperatures. The height of the two-phase area in Figure 3 corresponds to the change in temperature that will be required to force reaction (9) into completion. The reaction may also be accomplished by a change in $\mathrm{O}_{2}$ partial pressure, and the needed change should correspond to the required change in temperature. This suggests that mixtures with $\mathrm{Mn} /(\mathrm{Mn}+\mathrm{Fe})$ of $0.5-0.8$ would be particularly attractive for chemical-looping with oxygen uncoupling, since small changes in the surroundings would result in considerable $\mathrm{O}_{2}$ release.

Figure 4 shows equilibrium $\mathrm{O}_{2}$ partial pressure as function of temperature over $\left(\mathrm{Mn}_{0.8} \mathrm{Fe}_{0.2}\right) \mathrm{O}_{\mathrm{x}}$ and $\left(\mathrm{Mn}_{0.5} \mathrm{Fe}_{0.5} \mathrm{O}_{\mathrm{x}}\right.$. It can be seen that the combined spinel $\left(\mathrm{Mn}_{0.8} \mathrm{Fe}_{0.2}\right)_{3} \mathrm{O}_{4}$ can be completely oxidized to bixbyite $\left(\mathrm{Mn}_{0.8} \mathrm{Fe}_{0.2}\right)_{2} \mathrm{O}_{3}$ by $5 \% \mathrm{O}_{2}$ at temperatures below $\approx 890^{\circ} \mathrm{C}$, while the corresponding temperature for $\left(\mathrm{Mn}_{0.5} \mathrm{Fe}_{0.5}\right) \mathrm{O}_{\mathrm{x}}$ is $\approx 940^{\circ} \mathrm{C}$. Increasing the iron content above $50 \%$ would increase the possible temperature of operation further but also widen the twophase area, which likely is undesirable.

$\left(\mathrm{Mn}_{\mathrm{y}} \mathrm{Fe}_{1-\mathrm{y}}\right) \mathrm{O}_{\mathrm{x}}$ combined oxides has been examined as oxygen carrier for chemical-looping applications by Azimi et al. [8, 9, 10], Rydén et al. [11], Shulman et al. [12], Lambert et al. [13], and Ksepko et al. [14]. Studies [8-12] are all in good agreement with the reasoning presented above. In particular the study by Azimi et al. [8] which was conducted according to the principles proposed in this paper using $\left(\mathrm{Mn}_{0.8} \mathrm{Fe}_{0.2}\right) \mathrm{O}_{\mathrm{x}}$ as oxygen carrier, showed very fast $\mathrm{O}_{2}$ uncoupling and rapid oxidation of both methane and wood char already at $850^{\circ} \mathrm{C}$.

\section{$2.3 \quad\left(\mathrm{Mn}_{\mathrm{y}} \mathrm{Si}_{1-\mathrm{y}}\right) \mathrm{O}_{\mathrm{x}}$ combined oxides}

Manganese and silica oxides are cheap, could be expected to be inert towards sulfur at relevant temperatures and have low health and environmental impact. A binary phase diagram of this system is shown in Figure 5. It can be seen that the expected reaction mechanism for $\mathrm{O}_{2}$ release and uptake is different depending on the material composition.

With $\mathrm{Si} /(\mathrm{Mn}+\mathrm{Si})$ below 0.14 the system behaves similar to the pure manganese oxide system. If the surroundings have an $p_{O 2}$ of 0.05 atm, bixbyite $\mathrm{Mn}_{2} \mathrm{O}_{3}(M)$, is reduced to hausmannite spinel $\mathrm{Mn}_{3} \mathrm{O}_{4}(S)$ via reaction (7) at temperatures above $\approx 800^{\circ} \mathrm{C}$. Temperature for the transition increases as function of the Si content, which is expected to be present mainly as braunite $\mathrm{Mn}_{7} \mathrm{SiO}_{12}(B)$. The lower left corner of Figure 5 differs slightly from the classic 
studies by Muan et al. $[15,16]$, so the precise temperature for how much Si that is needed to increase the decomposition temperature in this region is somewhat unclear.

With $\mathrm{Si} /(\mathrm{Mn}+\mathrm{Si})$ above 0.14 the mechanism for $\mathrm{O}_{2}$ release is decomposition of braunite to $R$ rhodonite $\mathrm{MnSiO}_{3}(R)$, reaction (10). With $\mathrm{p}_{2}=0.05$ atm, reaction (10) goes to the right above $\approx 980^{\circ} \mathrm{C}$. Excess $\mathrm{Si}$ would in this case be inert and present as tridymite $\mathrm{SiO}_{2}(T)$.

$(2 / 3) \mathrm{Mn}_{7} \mathrm{SiO}_{12}+4 \mathrm{SiO}_{2} \leftrightarrow\left({ }^{14} / 3\right) \mathrm{MnSiO}_{3}+\mathrm{O}_{2}$

According to Figure 5, Reaction (10) can only go into completion in the first step if $\mathrm{Si} /(\mathrm{Mn}+\mathrm{Si})$ is equal to 0.50 , otherwise braunite or tridymite will be in excess. For $\mathrm{Si} /(\mathrm{Mn}+\mathrm{Si})$ of 0.14-0.50, further $\mathrm{O}_{2}$ release instead take place from conversion of rhodonite to tephroite $\mathrm{Mn}_{2} \mathrm{SiO}_{4}(E)$, reaction (11), which takes place in a second step at higher temperatures.

$\left({ }^{10} / 3\right) \mathrm{MnSiO}_{3}+\left({ }^{2} / 3\right) \mathrm{Mn}_{7} \mathrm{SiO}_{12} \leftrightarrow 4 \mathrm{Mn}_{2} \mathrm{SiO}_{4}+\mathrm{O}_{2}$

Figure 6 show equilibrium partial pressure of $\mathrm{O}_{2}$ as function of temperature over $\left(\mathrm{Mn}_{\mathrm{y}} \mathrm{Si}_{1-\mathrm{y}}\right) \mathrm{O}_{\mathrm{x}}$ combined oxides with $\mathrm{Si} /(\mathrm{Mn}+\mathrm{Si})$ larger than 0.14 . Complete oxidation with $5 \% \mathrm{O}_{2}$ should be possible at temperatures below $\approx 980^{\circ} \mathrm{C}$, which consequently should constitute a suitable air reactor temperature. Figure 6 is in good agreement with data provided by Muan et al. [16]. Up to this point, $\left(\mathrm{Mn}_{\mathrm{y}} \mathrm{Si}_{1-\mathrm{y}}\right) \mathrm{O}_{\mathrm{x}}$ combined oxides has not been widely examined as oxygen carrier for chemical-looping applications. Calvo [17] and Jing et al. [18] examined $\mathrm{O}_{2}$ release and reactivity with fuel gases at temperatures up to $1100^{\circ} \mathrm{C}$ for such oxygen carriers with $\mathrm{SiO}_{2}$ content ranging from 2-50 wt $\%$. All samples were found to release small amounts of $\mathrm{O}_{2}$, albeit some only at very high temperatures. In both studies reproducibility appears to have been a problem. At some occasions considerable $\mathrm{O}_{2}$ release was reported for initial experiments, but the effect diminished after several cycles or after reduction with fuel [17]. Other materials which initially did not release $\mathrm{O}_{2}$ in $\mathrm{N}_{2}$ at $900^{\circ} \mathrm{C}$ were found to release minor amounts following reduction with fuel and reoxidation [18]. At very high temperatures, particles with $30 \mathrm{wt} \% \mathrm{SiO}_{2}$ were found to release $\mathrm{O}_{2}$ more or less as suggested for reaction (11) in Figure 6, but full oxidation to $\mathrm{Mn}_{7} \mathrm{SiO}_{12}$ apparently was not possible [17]. The general impression for these two series of experiments is that oxidation to $\mathrm{Mn}_{7} \mathrm{SiO}_{12}, \mathrm{Mn}_{2} \mathrm{O}_{3}$ and $\mathrm{SiO}_{2}$ may have been slow or limited. Johansson et al. [19] examined oxygen carrier particles with $\mathrm{Si} /(\mathrm{Mn}+\mathrm{Si})$ of 0.68 , which were calcined in air at $950-1300^{\circ} \mathrm{C}$. No $\mathrm{O}_{2}$ release in inert atmosphere was reported, but the phase composition of the particles was consistent with Figure 5, i.e. particles calcined at $950-1100^{\circ} \mathrm{C}$ consisted of $\mathrm{Mn}_{7} \mathrm{SiO}_{12}$ and $\mathrm{SiO}_{2}$, while particles calcined at $1200-1300^{\circ} \mathrm{C}$ also contained $\mathrm{MnSiO}_{3}$. Shulman et al. [12] prepared oxygen carriers with $\mathrm{Si} /(\mathrm{Mn}+\mathrm{Si})$ of 0.24 which were calcined in air at $950-1100^{\circ} \mathrm{C}$. The 
resulting particles reportedly consisted of $\mathrm{Mn}_{2} \mathrm{O}_{3}$ and $\mathrm{SiO}_{2}$ and released $\mathrm{O}_{2}$ during fluidization with $\mathrm{N}_{2}$, following oxidation with $10 \% \mathrm{O}_{2}$ in $\mathrm{N}_{2}$ The $\mathrm{O}_{2}$ release was quite high at $850^{\circ} \mathrm{C}$, up to $2.5 \%$, only to fall back to almost zero at $900^{\circ} \mathrm{C}$. Lack of $\mathrm{O}_{2}$ release at $900^{\circ} \mathrm{C}$ suggests that the mechanism could have been reaction (7), for which reoxidation to $\mathrm{Mn}_{2} \mathrm{O}_{3}$ should not have been possible at $900^{\circ} \mathrm{C}$ using the described process conditions. In any case, these observations as well as the phase composition of the fresh particles is inconsistent with Figures 5-6.

To summarize; thermodynamic analysis suggests that $\left(\mathrm{Mn}_{\mathrm{y}} \mathrm{Si}_{1-\mathrm{y}}\right) \mathrm{O}_{\mathrm{x}}$ combined oxides could work excellently as oxygen carrier for chemical-looping with oxygen uncoupling. There is limited experimental experience with this kind of materials though and the results fit poorly with theoretical analysis.

\section{4 $\mathrm{CaMnO}_{3-\delta}$ and other materials of perovskite structure}

Materials of perovskite structure have a unit cell which can be written $\mathrm{ABO}_{3-\delta}$, in which $\mathrm{A}$ is a large cation and $\mathrm{B}$ is a smaller cation. The $\delta$-factor expresses the degree of oxygen deficiency in the structure, and is zero for a perfect structure.

There are countless possibilities to synthesize materials of perovskite structure. The A and B sites does not have to consist of one single type of ions. Doping of the A and B site with one or more type of ions is possible as long as the dopants have similar ionic radii and oxidation state as the main atom. Generally speaking, the B site can be selected among most transition metal ions. Good candidates for the application chemical-looping combustion could be for example manganese, iron and titania, albeit small amounts of more expensive materials such as copper, nickel or cobalt could be included in the structure as well. The A site needs to have much larger ionic radii and there are less options. Calcium appears to be the most attractive due to good availability and low cost, with the most commonly examined alternatives being lanthanum and strontium. Finally, the sum of the expected oxidation number of the A and B site should be in the range 5-6, which would yield materials with a $\delta$-factor of $0.5-0$. The formability of perovskites has been extensively reviewed by Li et al. [20].

Materials of perovskite structure are interesting for chemical-looping applications because $\delta$ can be increased or reduced by altering factors in the surroundings such as temperature, pressure or $\mathrm{O}_{2}$ fugacity. The surroundings in a chemical-looping air reactor are oxidative, while they are reductive in the fuel reactor. Therefore $\delta_{\text {ar }}$ will be smaller and $\delta_{\text {fr }}$ will be larger. The amount of $\mathrm{O}_{2}$ available for oxidation of fuel can be written as $\left(\delta_{\mathrm{fr}}-\delta_{\mathrm{ar}}\right)$, see reaction (12). $\mathrm{ABO}_{3-\delta a r} \leftrightarrow \mathrm{ABO}_{3-\delta \mathrm{fr}}+1 / 2\left(\delta_{\mathrm{fr}}-\delta_{\mathrm{ar}}\right) \mathrm{O}_{2}$ 
Not all materials with perovskite structure undergo reaction (12) at conditions suitable for chemical-looping combustion. Instead, the properties of a certain material will depend on nature of the A and B sites. One proposed material composition which has proven to be of interests for chemical looping combustion is calcium manganite $\mathrm{CaMnO}_{3-\delta}$, and slightly altered variants thereof. Rydén et al. [21] examined $\mathrm{CaMn}_{0.875} \mathrm{Ti}_{0.125} \mathrm{O}_{3-\delta}$ in a small circulating fluidized bed reactor and reported good fluidization behavior, stable operation, $\mathrm{O}_{2}$ release in inert atmosphere and that complete conversion of $\mathrm{CH}_{4}$ was achievable. Leion et al. [22] examined $\mathrm{CaMn}_{1-\mathrm{x}} \mathrm{Ti}_{\mathrm{xO} 3-\delta}$ both in a thermo gravimetric analyzer and in batch fluidized bed reactor. The materials were found to have high reactivity with $\mathrm{CH}_{4}$ and petroleum coke and released $\mathrm{O}_{2}$ in gas phase when fluidized with $\mathrm{N}_{2}$. Further, it was possible to remove as much as $8-9 \mathrm{wt} \% \mathrm{O}_{2}$ from the particles without collapsing the perovskite structure which suggests a feasible operating span ranging from $\delta$ of 0 to about 0.7 . Hallberg et al. [23] examined $\mathrm{CaMnO}_{3-\delta}$ oxygen carriers with the $\mathrm{B}$ site doped with $\mathrm{Fe}$, Ti, and $\mathrm{Mg}$ with good results, while Fossdal et al. [24] successfully manufactured $\mathrm{CaMnO}_{3-\delta}$ oxygen carrier materials from manganese ore and calcium hydroxide.

With respect to direct release of gas phase $\mathrm{O}_{2}$ in inert atmosphere, different dynamics could be expected compared to materials which undergo distinct phase changes. Figure 7 describes $\delta$ at equilibrium as function of $\mathrm{O}_{2}$ partial pressure. It can be seen that $\mathrm{O}_{2}$ could be expected to be released at comparably high concentrations initially, when $\delta$ is at its minimum. But as $\mathrm{O}_{2}$ is removed from the perovskite structure and $\delta$ increases, the obtained $\mathrm{O}_{2}$ partial pressure is continuously reduced in a logarithmic fashion. This behavior has been documented for example by Leion et al. [22] and Hallberg et al. [23] during experiments in batch fluidized bed reactor.

It is evident from Figure 7 that the higher $\mathrm{O}_{2}$ partial pressure which is used for oxidation, the more $\mathrm{O}_{2}$ can be transported to an inert or low $\mathrm{O}_{2}$ atmosphere. For example, oxidation with $21 \% \mathrm{O}_{2}$ and $\log \left(\mathrm{pO}_{2} / \mathrm{atm}\right)=-0.678$ at $950^{\circ} \mathrm{C}$ and atmospheric pressure would result in $\mathrm{CaMnO}_{2.95}$, while oxidation with $5 \% \mathrm{O}_{2}$ and $\log \left(\mathrm{p}_{\mathrm{O} 2} / \mathrm{atm}\right)=-1.301$ at the same conditions would result in $\mathrm{CaMnO}_{2.92}$. Consider a second process step in which gaseous $\mathrm{O}_{2}$ would be released in an atmosphere with $0.1 \% \mathrm{O}_{2}$ and $\log \left(\mathrm{p}_{\mathrm{O} 2} / \mathrm{atm}\right)=-3.000$ and the final product could be expected to be $\mathrm{CaMnO}_{2.85}$. In the first case, the $\mathrm{O}_{2}$ release according to reaction (12) would be $1 / 2 \cdot(0.15-0.05)=0.050 \mathrm{~mol} \mathrm{O}_{2}(\approx 1.1 \mathrm{wt} \%)$, compared to $1 / 2 \cdot(0.15-0.08)=0.035 \mathrm{~mol} \mathrm{O}_{2}(\approx 0.8$ wt \%). This mechanism described has been verified by Rydén et al. [21] by conducting experiments in a small circulating fluidized bed reactor, in which it was seen that $\mathrm{O}_{2}$ release 
was considerably higher when oxidizing $\mathrm{CaMn}_{0.875} \mathrm{Ti}_{0.125} \mathrm{O}_{3-\delta}$ with air rather than with a mixture consisting of $5 \% \mathrm{O}_{2}$ and $95 \% \mathrm{~N}_{2}$.

\section{$2.5 \quad\left(\mathrm{Mn}_{\mathrm{y}} \mathrm{Ni}_{1-\mathrm{y}}\right) \mathrm{O}_{\mathrm{x}}$ combined oxides}

Shulman et al. [12] examined oxygen carrier particles consisting of $80 \mathrm{wt} \% \mathrm{Mn}_{3} \mathrm{O}_{4}$ and 20 $\mathrm{wt} \% \mathrm{NiO}$ calcined in air at $950-1300^{\circ} \mathrm{C}$, all of which reportedly consisted of mostly of $\mathrm{NiMn}_{2} \mathrm{O}_{4}$ spinel, as per XRD of fresh materials. During fluidization with $\mathrm{N}_{2}$ small amounts of $\mathrm{O}_{2}$ were released at $810-900^{\circ} \mathrm{C}$. The likely mechanism is decomposition into manganese-rich spinel $\left(\mathrm{Mn}_{\mathrm{y}} \mathrm{Ni}_{1-\mathrm{y}}\right)_{3} \mathrm{O}_{4}$ and nickel-rich $\left(\mathrm{Ni}_{\mathrm{y}} \mathrm{Mn}_{1-\mathrm{y}}\right) \mathrm{O}$ of rock-salt structure, reaction (13), as have been reported by Csete de Györgyfalva and Reaney [26].

$6 \mathrm{NiMn}{ }_{2} \mathrm{O}_{4} \leftrightarrow 6 \mathrm{NiO}+4 \mathrm{Mn}_{3} \mathrm{O}_{4}+\mathrm{O}_{2}$

The reported temperature of decomposition of $\mathrm{NiMn}_{2} \mathrm{O}_{4}$ in air according to reaction (13) is $907^{\circ} \mathrm{C}$ [26]. This suggests that reoxidation could be a problem when using low $\mathrm{O}_{2}$ concentrations. Shulman et al. [12] were capable to oxidize to oxidize particles using $10 \% \mathrm{O}_{2}$ in $\mathrm{N}_{2}$ at $900^{\circ} \mathrm{C}$ though. In general, these results appear to be in good agreement with the phase diagram provided by Golikov and Balakirev [27].

Despite these promising results, the allure of $\left(\mathrm{Mn}_{\mathrm{y}} \mathrm{Ni}_{1-\mathrm{y}}\right) \mathrm{O}_{\mathrm{x}}$ combined oxides as oxygen carrier for chemical-looping applications is not necessarily high. Ni is expensive and carcinogenic and would probably be more useful as monometallic oxygen carrier since direct reduction of $\mathrm{NiO}$ yields metallic $\mathrm{Ni}$, which is well-known to possess some interesting catalytic properties.

\section{6 $\left(\mathrm{Mn}_{\mathrm{y}} \mathrm{Cu}_{1-\mathrm{y}}\right) \mathrm{O}_{\mathrm{x}}$ combined oxides}

Since both manganese and copper oxides individually has properties which makes them interesting for chemical-looping with oxygen uncoupling, it could be expected that $\left(\mathrm{Mn}_{\mathrm{y}} \mathrm{Cu}_{1-\mathrm{y}}\right) \mathrm{O}_{\mathrm{x}}$ combined oxides should form compounds or solid solutions capable of releasing $\mathrm{O}_{2}$ in the relevant temperature span as well. Azad et al. [28] synthesized particles with a $\mathrm{Mn} / \mathrm{Cu}$ ratio of 2 via extrusion and calcination at $950^{\circ} \mathrm{C}$. XRD analysis showed that the fresh and oxidized material consisted of one or several combined spinel phases $\left(\mathrm{Mn}_{\mathrm{y}} \mathrm{Cu}_{1-\mathrm{y}}\right)_{3} \mathrm{O}_{4}$, while particles reduced with fuel gas at $850^{\circ} \mathrm{C}$ consisted mostly of cerdnerite $\mathrm{CuMnO}_{2}$ and hausmannite $\mathrm{Mn}_{3} \mathrm{O}_{4}$. The particles provided high reactivity with $\mathrm{CH}_{4}$ and released up to $2.5 \% \mathrm{O}_{2}$ when fluidized with $\mathrm{N}_{2}$ at $850^{\circ} \mathrm{C}$. Reaction (14) illustrates the expected reaction mechanism for the stoichiometric spinel:

$3 \mathrm{CuMn}_{2} \mathrm{O}_{4} \leftrightarrow 3 \mathrm{CuMnO}_{2}+\mathrm{Mn}_{3} \mathrm{O}_{4}+\mathrm{O}_{2}$ 
These observations are in accordance with the phase diagram suggested by Driessens and Rieck [29], whose work also indicates that all $\left(\mathrm{Mn}_{\mathrm{y}} \mathrm{Cu}_{1-\mathrm{y}}\right) \mathrm{O}_{\mathrm{x}}$ combined oxides could release gas phase $\mathrm{O}_{2}$ at relevant temperatures, albeit via complex reactions schemes and at lower temperatures than for pure $\mathrm{CuO}$. Whether this option could be interesting for chemicallooping applications remains to be explored.

\section{$2.7 \quad\left(\mathrm{Mn}_{\mathrm{y}} \mathrm{Mg}_{1-\mathrm{y}}\right) \mathrm{O}_{\mathrm{x}}$ combined oxides}

The following solid solutions and compounds are said to exist below $1000^{\circ} \mathrm{C}$ in the $\mathrm{Mn}-\mathrm{Mg}-\mathrm{O}$ ternary system according to Valverde-Diez and Grande-Fernándes [30]:

a) Compounds $\mathrm{Mg}_{6} \mathrm{MnO}_{8}, \mathrm{Mg}_{2} \mathrm{MnO}_{4}$ and $\mathrm{MgMn}_{2} \mathrm{O}_{4}$.

b) Solid solution $\left(\mathrm{Mg}_{\mathrm{x}} \mathrm{Mn}_{3-\mathrm{x}}\right) \mathrm{O}_{4}$ with $0<\mathrm{x}<2$ which has a spinel structure.

c) Solid solution $\left(\mathrm{Mg}_{\mathrm{x}} \mathrm{Mn}_{1-\mathrm{x}}\right) \mathrm{O}$ with $0<\mathrm{x}<0.33$ which has a rock-salt structure.

Shulman et al. [31] successfully prepared several oxygen carrier particles with $\mathrm{Mg} / \mathrm{Mn}$ ratio of 2 and calcination in air at $1100-1300^{\circ} \mathrm{C}$, all of which reportedly consisted of $\mathrm{Mg}_{2} \mathrm{MnO}_{4}$, as per XRD analysis of fresh particles. This corresponds to $2 \mathrm{MgO} \cdot \mathrm{MnO}_{2}$ and an oxidation state of manganese ions of $\mathrm{Mn}^{+4}$, which seems quite remarkable. In inert atmosphere and elevated temperature, $\mathrm{O}_{2}$ could be expected to be released via reaction (15), which illustrates reduced solubility of $\mathrm{Mg}$ in the spinel solid solution. The simplified reactions (16-17) is for stoichiometric compounds:

$$
\begin{aligned}
& \mathrm{Mg}_{2} \mathrm{MnO}_{4} \leftrightarrow[1-(1 /(1+\mathrm{x}))]\left(\mathrm{Mg}_{2-\mathrm{x}} \mathrm{Mn}_{1+\mathrm{x}}\right) \mathrm{O}_{4}+[1+\mathrm{x}] \mathrm{MgO}+[1 /(1+\mathrm{x})] \mathrm{O}_{2} \\
& 4 \mathrm{Mg}_{2} \mathrm{MnO}_{4} \leftrightarrow 2 \mathrm{MgMn}_{2} \mathrm{O}_{4}+6 \mathrm{MgO}+\mathrm{O}_{2} \\
& 6 \mathrm{MgMn}_{2} \mathrm{O}_{4} \leftrightarrow 4 \mathrm{Mn}_{3} \mathrm{O}_{4}+6 \mathrm{MgO}+\mathrm{O}_{2}
\end{aligned}
$$

From the work of Shulman et al. [31] and earlier work with this system by Oliveira and Brett [32], it seems likely that reaction (15) takes place at higher temperatures than for monometallic manganese oxides and via a sliding equilibrium for $\mathrm{O}_{2}$ partial pressure depending on the factor $\mathrm{x}$ in reaction (15). Further work will be needed in order to provide a better understanding of this oxide system though.

\section{$3 \quad$ Results and discussion}

The focus of this article has been on combined oxides with manganese as one of its constituents. That is not to say that other ternary systems do not exhibit this kind of 
properties. We believe that the case for manganese is pretty good though, since it is a cheap and comparably benign transition metal which forms compounds with a large number of other elements and which ions can exist in a remarkably high number of oxidation states, from $\mathrm{Mn}^{2+}$ to $\mathrm{Mn}^{7+}$. A summary of the most basic properties for the materials suggested in this work can be found in Table 1 on the following page.

In Table 1, it can be seen that most manganese based combined oxides has considerably lower oxygen carrying capacity $\mathrm{R}_{0}$, compared to $\mathrm{CuO}$. Values of $2-3 \mathrm{wt} \%$ should still be sufficient for practical applications though.

$\Delta \mathrm{H}$ for $\mathrm{O}_{2}$ release typically is in the range $250-325 \mathrm{~kJ} / \mathrm{mol} \mathrm{O}_{2}$, i.e. pretty similar to that of $\mathrm{CuO}$. If compared to the enthalpy of combustion at $900^{\circ} \mathrm{C}$ for methane $\left(-401 \mathrm{~kJ} / \mathrm{mol} \mathrm{O} \mathrm{O}_{2}\right)$ and carbon $\left(-379 \mathrm{~kJ} / \mathrm{mol} \mathrm{O}_{2}\right)$, it is evident that the overall reaction in the fuel reactor typically will be slightly exothermic. As explained above, this could be favorable since it simplifies closure of the heat balance for the fuel reactor. It shall be pointed out that endothermic reaction in the fuel reactor using oxygen carriers with $\mathrm{O}_{2}$ release is a possibility, and should be the case for example if $\mathrm{Co}_{3} \mathrm{O}_{4}-\mathrm{CoO}$ is used, as can be seen in Table 1.

Of the suggested systems, some could be suspicable to deactivation by fuel impurities. The sulfur tolerance of oxygen carriers containing for example $\mathrm{Ca}, \mathrm{Mg}$ and $\mathrm{Ni}$ is unknown but questionable, since formation of stable sulfates and sulfides would be favored at relevant temperatures. The effect of sulfur on such oxygen carriers will need to be carefully considered and experimentally examined.

Factors which have not been considered in this paper are for example mechanical and chemical stability of multiphase materials, which could be problematic. Compatibility of the active phase with inert support materials would also get more complicated the more elements are included in the oxygen carrier. Manufacturing would probably not be more complicated for combined oxides compared to monometallic, although better homogenization and higher calcination temperatures may be necessary to obtain the desired materials.

\section{Conclusions}

This paper has provided an overview of the possibility to design feasible oxygen carrier materials from combined oxides. Current literature has been reviewed and complemented with thermodynamic calculations. It can be concluded that there are several opportunities with the most interesting ones being materials based on the general formulas $\left(\mathrm{Mn}_{\mathrm{y}} \mathrm{Fe}_{1-\mathrm{y}}\right) \mathrm{O}_{\mathrm{x}}$, $\left(\mathrm{Mn}_{\mathrm{y}} \mathrm{Si}_{1-\mathrm{y}}\right) \mathrm{O}_{\mathrm{x}}$ and $\mathrm{CaMnO}_{3-\delta}$. 


\section{$5 \quad$ Acknowledgement}

This work was carried out with support from the European Research Council (Novel combustion principle with inherent capture of $\mathrm{CO}_{2}$ using combined manganese oxides that release oxygen, ERC Advanced Grant).

\section{References}

[1] Adanez J, Abad A, Garcia-Labiano F, Gayan P, de Diego LF. Progress in ChemicalLooping Combustion and Reforming technologies. Progress in Energy and Combustion Science 2012;38:215-282.

[2] Lyngfelt A. Oxygen Carriers for Chemical Looping Combustion - $4000 \mathrm{~h}$ of Operational Experience. Oil \& Gas Science and Technology - Revue d'IFP Energies nouvelles 2011;66:161-172.

[3] Mattisson T, Lyngfelt A, Leion H. Chemical-looping with oxygen uncoupling for combustion of solid fuels. International Journal of Greenhouse Gas Control 2009;3:11-19.

[4] Leion H, Mattisson T, Lyngfelt A. Using chemical-looping with oxygen uncoupling (CLOU) for combustion six different of solid fuels. Energy Procedia 2009;1:447-453.

[5] Gayán P, Adánez-Rubio I, Abad A, De Diego LF, García-Labiano F, Adánez J. Development of $\mathrm{Cu}$-based oxygen carriers for Chemical-Looping with Oxygen Uncoupling (CLOU) process. Fuel 2012;96:226-238.

[6] Eyring EM, Konya G, Lighty JS, Sahir AH, Sarofim AF, Whitty K. Chemical Looping with Copper Oxide as Carrier and Coal as Fuel. Oil \& Gas Science and Technology - Revue d'IFP Energies nouvelles 2011;66:209-221.

[7] Arjmand M, Azad AM, Leion H, Lyngfelt A, Mattisson T. Prospects of $\mathrm{Al}_{2} \mathrm{O}_{3}$ and $\mathrm{MgAl}_{2} \mathrm{O}_{4}$-Supported $\mathrm{CuO}$ Oxygen Carriers in Chemical-Looping Combustion (CLC) and Chemical-Looping with Oxygen Uncoupling (CLOU). Energy Fuels 2011;25:5493-5502.

[8] Azimi G, Rydén M, Leion H, Mattisson T, Lyngfelt A. $\left(\mathrm{Mn}_{\mathrm{y}} \mathrm{Fe}_{1-\mathrm{y}}\right) \mathrm{O}_{\mathrm{x}}$ combined oxides as oxygen carrier for chemical-looping with oxygen uncoupling (CLOU). In press, AIChE Journal, DOI: 10.1002/aic.13847.

[9] Azimi G, Leion H, Rydén M, Mattisson T, Lyngfelt A. Investigation of different Mn-Fe oxides as oxygen carrier for Chemical-Looping with Oxygen Uncoupling (CLOU). Submitted for publication. 
[10] Azimi G, Leion H, Mattisson T, Lyngfelt A. Chemical-Looping with Oxygen Uncoupling using combined Mn-Fe oxides, testing in batch fluidized bed. Energy Procedia 2011;4:370-377.

[11] Rydén M, Lyngfelt A, Mattisson T. Combined manganese/iron oxides as oxygen carrier for chemical looping combustion with oxygen uncoupling (CLOU) in a circulating fluidized bed reactor system. Energy Procedia 2011;4:341-348.

[12] Shulman A, Cleverstam E, Mattisson T, Lyngfelt A. Manganese/Iron, Manganese/Nickel, and Manganese/Silicon Oxides Used in Chemical-Looping With Oxygen Uncoupling (CLOU) for Combustion of Methane. Energy Fuels 2009;23:5269-5275.

[13] Lambert A, Delquié B, Clémeneçon I, Comte E, Lefebvre V, Rousseau J, Durand B. Synthesis and characterization of bimetallic Fe/Mn oxides for chemical looping combustion. Energy Procedia 2009;1:375-381.

[14] Ksepko E, Siriwardane RV, Tian H, Simonyi T, Sciazko M. Effect of $\mathrm{H}_{2} \mathrm{~S}$ on Chemical Looping Combustion of Coal-Derived Synthesis Gas over Fe-Mn Oxides Supported on Sepiolite, $\mathrm{ZrO}_{2}$, and $\mathrm{Al}_{2} \mathrm{O}_{3}$. Energy \& Fuels 2012;26:2461-2472.

[15] Muan A. Phase equilibria in the system manganese oxide- $\mathrm{SiO}_{2}$ in air. American Journal of Science 1959;257:297-315.

[16] Muan A. Stability relations among some manganese minerals. The American Mineraralogist 1959;44:946-960.

[17] Calvo D. Evaluation of manganese silicate as oxygen carrier for chemical looping combustion at high temperatures. Master's Thesis to be published by Chalmers University of Technology.

[18] Jing D, Hermans E, Leion H, Rydén M, Mattisson T, Lyngfelt A. Manganese silica combined oxide as oxygen carrier for chemical-looping combustion. Proceedings of the 2nd International Conference on Chemical Looping, 26-28 September 2012, Darmstadt, Germany. [19] Johansson M, Mattisson T, Lyngfelt A. Comparison of oxygen carriers for chemicallooping combustion. Thermal Science 2006;10:93-107.

[20] $\mathrm{Li} \mathrm{C}$, Soh KCK, Wu P. Formability of $\mathrm{ABO}_{3}$ perovskites. Journal of alloys and compounds 2004;372:40-48.

[21] Rydén M, Lyngfelt A, Mattisson T. $\mathrm{CaMn}_{0.875} \mathrm{Ti}_{0.125} \mathrm{O}_{3-\delta}$ as oxygen carrier for chemicallooping combustion with oxygen uncoupling (CLOU) - experiments in continuously 
operating fluidized bed reactor system. International Journal of Greenhouse Gas Control 2011;5:356-366.

[22] Leion H, Larring Y, Bakken E, Mattisson T, Bredesen R, Lyngfelt A. The use of $\mathrm{CaMn}_{0.875} \mathrm{Ti}_{0.125} \mathrm{O}_{3}$ as oxygen carrier in Chemical-Looping with Oxygen Uncoupling (CLOU), Energy \& Fuels 2009;23:5276-5283.

[23] Hallberg P, Jing D, Rydén M, Mattisson T, Lyngfelt A. Chemical Looping with Oxygen Uncoupling experiments in a batch reactor using spray dried $\mathrm{CaMn}_{(1-\mathrm{x})} \mathrm{M}_{\mathrm{x}} \mathrm{O}_{3-\delta}(\mathrm{M}=\mathrm{Ti}, \mathrm{Fe}, \mathrm{Mg})$ particles as Oxygen Carriers. Submitted for publication

[24] Fossdal A, Bakken E, Øye B.A, Schøning C, Kaus, I, Mokkelbost, T, Larring, Y. Study of inexpensive oxygen carriers for chemical looping combustion. International Journal of Greenhouse Gas Control 2011;5: 483-488.

[25] Leonidova EI, Leonidov IA, Patrakeev MV, Kozhevnikov VL. Oxygen nonstoichiometry, high-temperature properties, and phase diagram of $\mathrm{CaMnO}_{3-\delta}$, Journal of Solid State Electrochemistry 2011;15:1071-1075.

[26] Csete de Györgyfalva GDC, Reaney IM. Decomposition of $\mathrm{NiMn}_{2} \mathrm{O}_{4}$ spinel: An NTC thermistor material, Journal of the European Ceramic Society 2011;21:2145-2148.

[27] Golikov YV, Balakirev VF. Phase equilibrium diagram of the system - Ni-Mn-O, Journal of Physics and Chemistry of Solids 1986;49:329-332.

[28] Azad AM, Hedayati A, Rydén M, Leion H, Mattisson T. (2012), Examining the Cu-MnO Spinel System as an Oxygen Carrier in Chemical Looping Combustion. Submitted for publication.

[29] Driessens FCM, Rieck GD. Phase equilibria in the system Cu-Mn-O. Zeitschrift für anorganische und allgemeine Chemie 1967;351:48-62.

[30] Valverde-Diez N, Grande-Fernández D. Ternary compounds of the system Mg-Mn-O as oxygen sensors. Solid State Ionics 1988;28-30:1697-1700.

[31] Shulman A, Cleverstam E, Mattisson T, Lyngfelt A. Chemical-Looping with Oxygen Uncoupling using Mn/Mg-based Oxygen Carriers for Methane Combustion. Fuel 2011;90:941-950.

[32] Oliviera VAG, Brett NH. Phase equilibria in the system $\mathrm{MgO}-\mathrm{Mn}_{2} \mathrm{O}_{3}-\mathrm{MnO}-\mathrm{CaSiO}{ }_{3}$ in air, Journal De Physique 1986;47:C1-453. 
[33] Robie AR, Huebner JS, Hemingway BS. Heat capacity and thermodynamic properties of braunite $\left(\mathrm{Mn}_{7} \mathrm{SiO}_{12}\right)$ and rhodonite $\left(\mathrm{MnSiO}_{3}\right)$, American Mineralogist 1995;80:560-575.

[34] Rørmark L, Mørch AB, Wiik K, Stølen S, Grande T. Enthalpies of oxidation of $\mathrm{CaMnO}_{3-\delta}, \mathrm{Ca}_{2} \mathrm{MnO}_{4-\delta}$ and $\mathrm{SrMnO}_{3-\delta}$ - deduced redox properties. Chemistry of Materials 2001;13:4005-4013. 


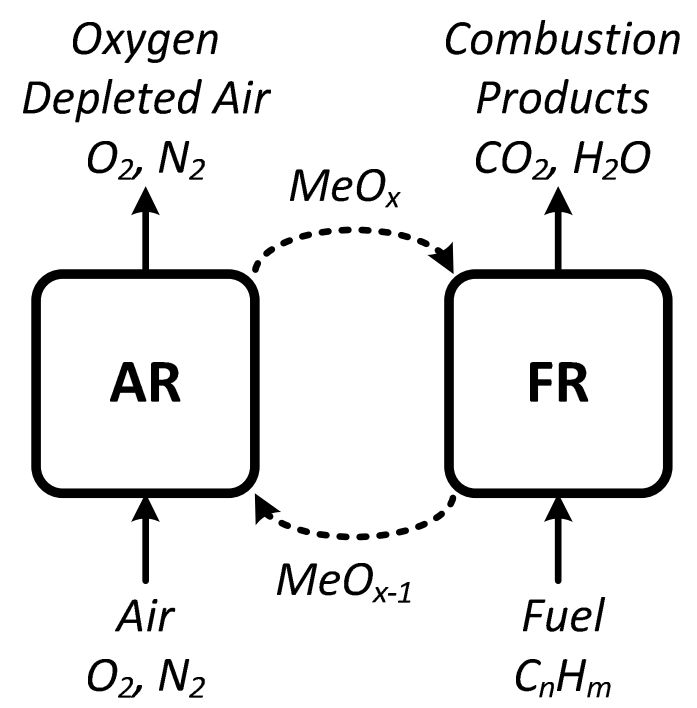

Figure 1: Schematic description of chemical-looping combustion (CLC) and chemicallooping with oxygen uncoupling (CLOU). 


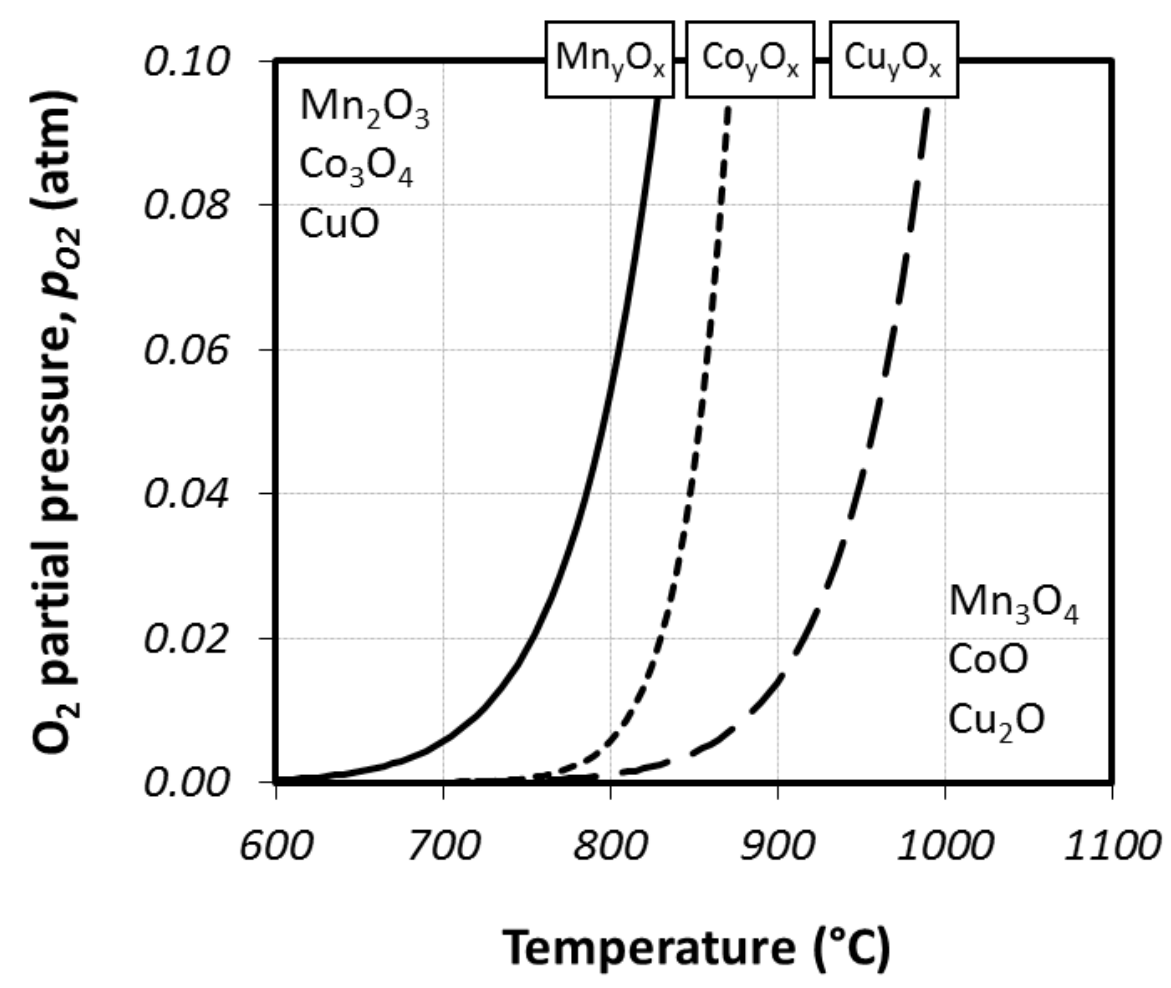

Figure 2: Equilibrium $\mathrm{O}_{2}$ partial pressure of as function of temperature for selected monometallic oxygen carriers. 


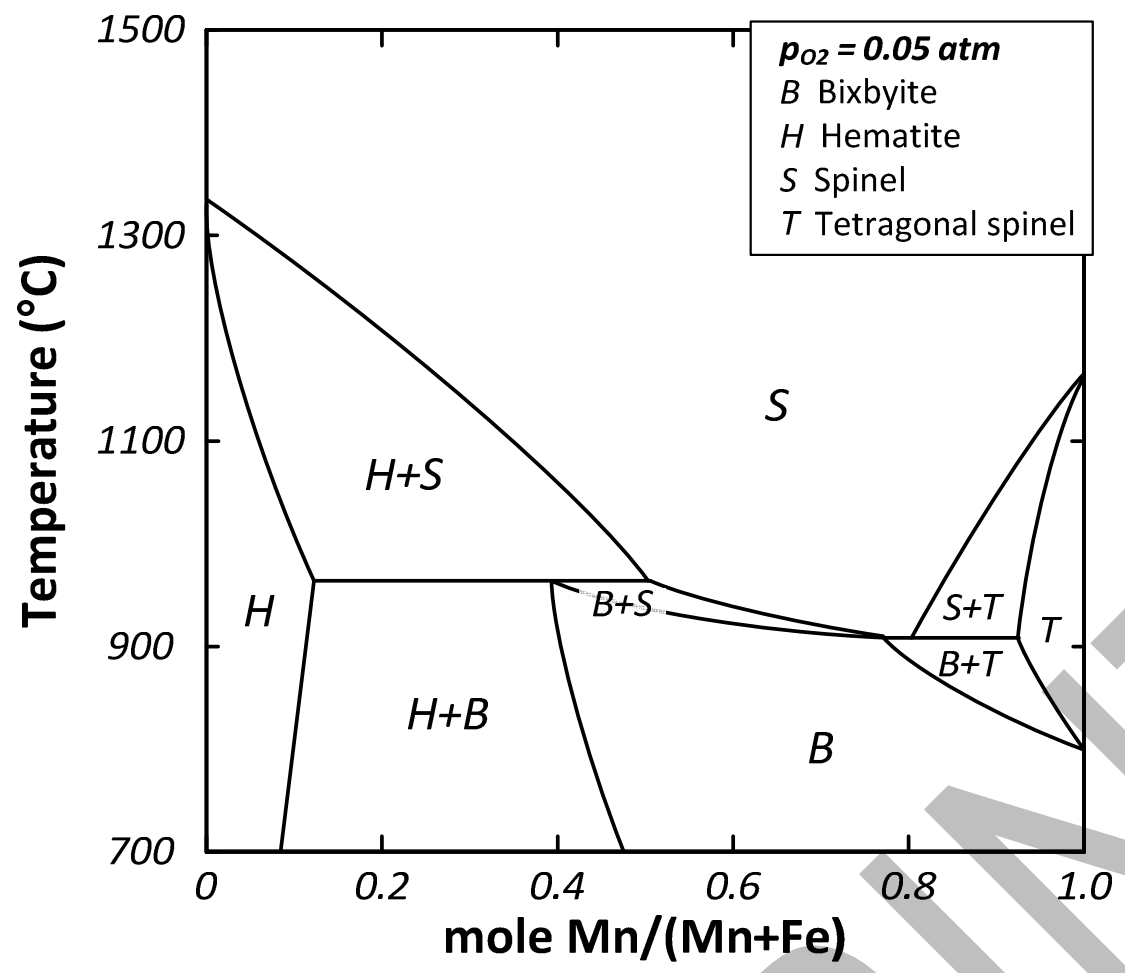

Figure 3: Binary phase diagram of $\left(\mathrm{Mn}_{y} \mathrm{Fe}_{1-y}\right) \mathrm{O}_{x}$ in an atmosphere with an $\mathrm{O}_{2}$ partial pressure of $0.05 \mathrm{~atm}$. 


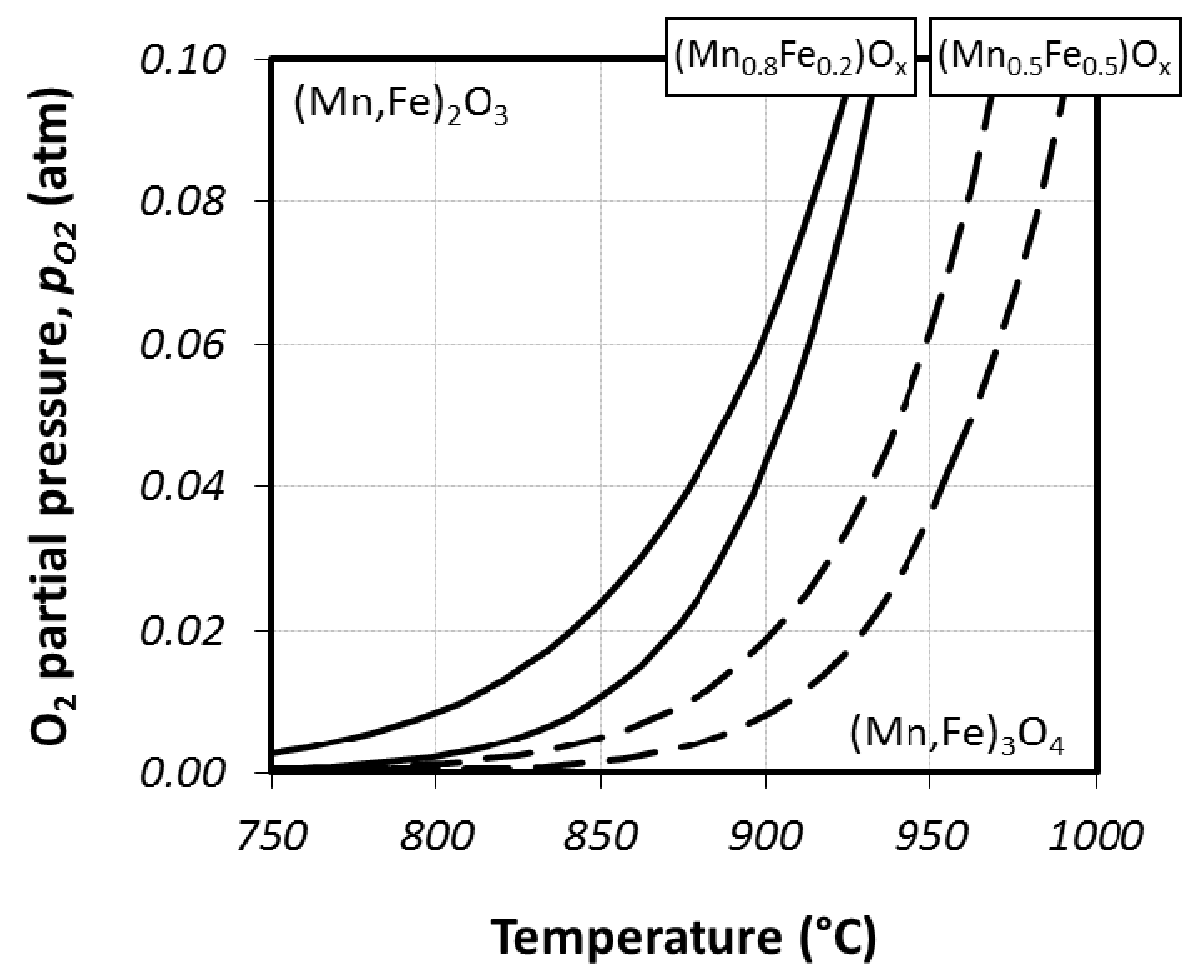

Figure 4: $\mathrm{p}_{\mathrm{O} 2}$ as function of temperature over $\left(\mathrm{Mn}_{\mathrm{x}} \mathrm{Fe}_{1-\mathrm{x}}\right) \mathrm{O}_{\mathrm{x}}$. Area enclosed by each set of curves represents the two-phase area where bixbyite and spinel phases coexists. 


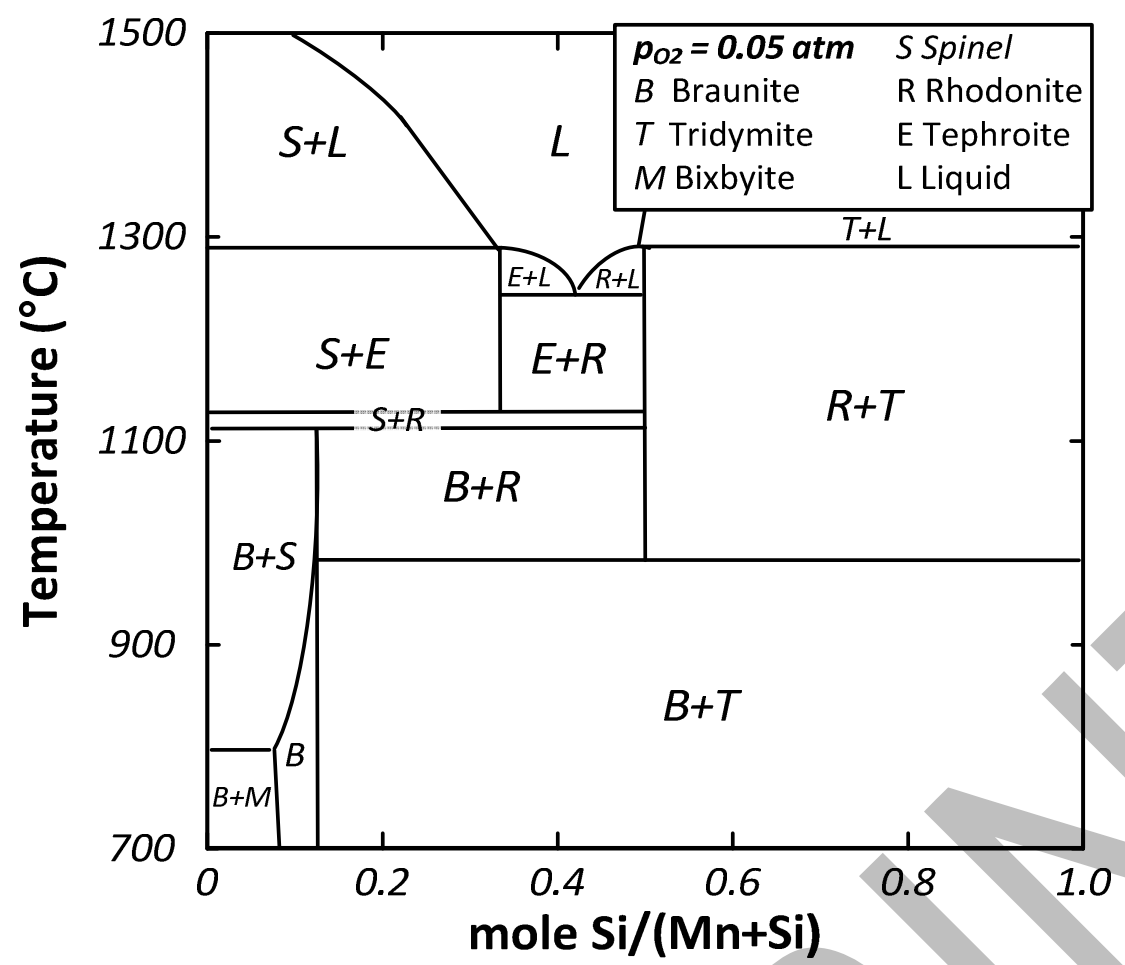

Figure 5: Binary phase diagram of $\left(\mathrm{Mn}_{y} \mathrm{Si}_{1-y}\right) \mathrm{O}_{x}$ in an atmosphere with an $\mathrm{O}_{2}$ partial pressure of $0.05 \mathrm{~atm}$. 


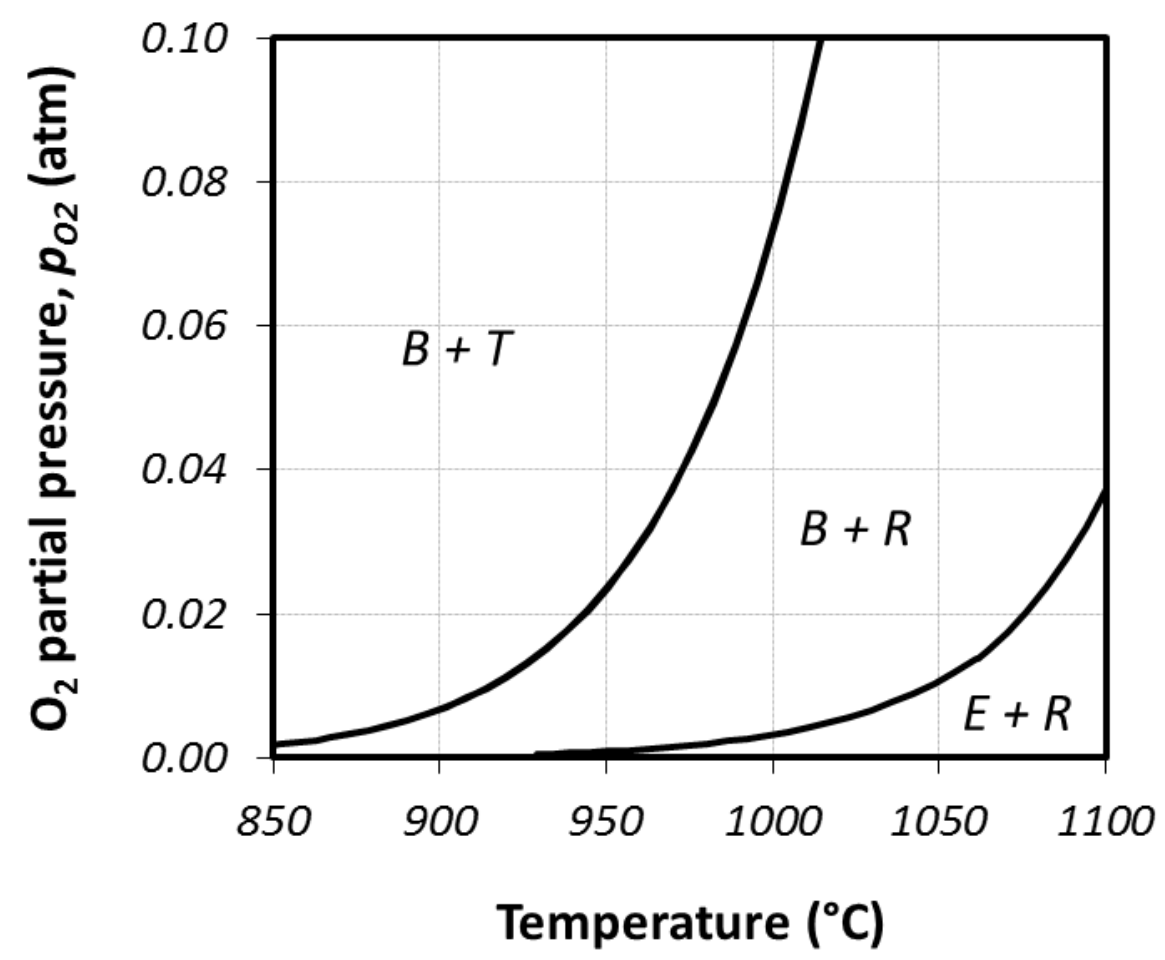

Figure 6: $\mathrm{p}_{\mathrm{O} 2}$ as function of temperature over $\left(\mathrm{Mn}_{\mathrm{y}} \mathrm{Si}_{1-y}\right) \mathrm{O}_{\mathrm{x}}$ combined oxides with $\mathrm{Si} /(\mathrm{Mn}+\mathrm{Si})$ above 0.14 . Transition to $\mathrm{Mn}_{2} \mathrm{SiO}_{4}$ only valid for $\mathrm{Si} /(\mathrm{Mn}+\mathrm{Si})$ 0.14-0.50. 


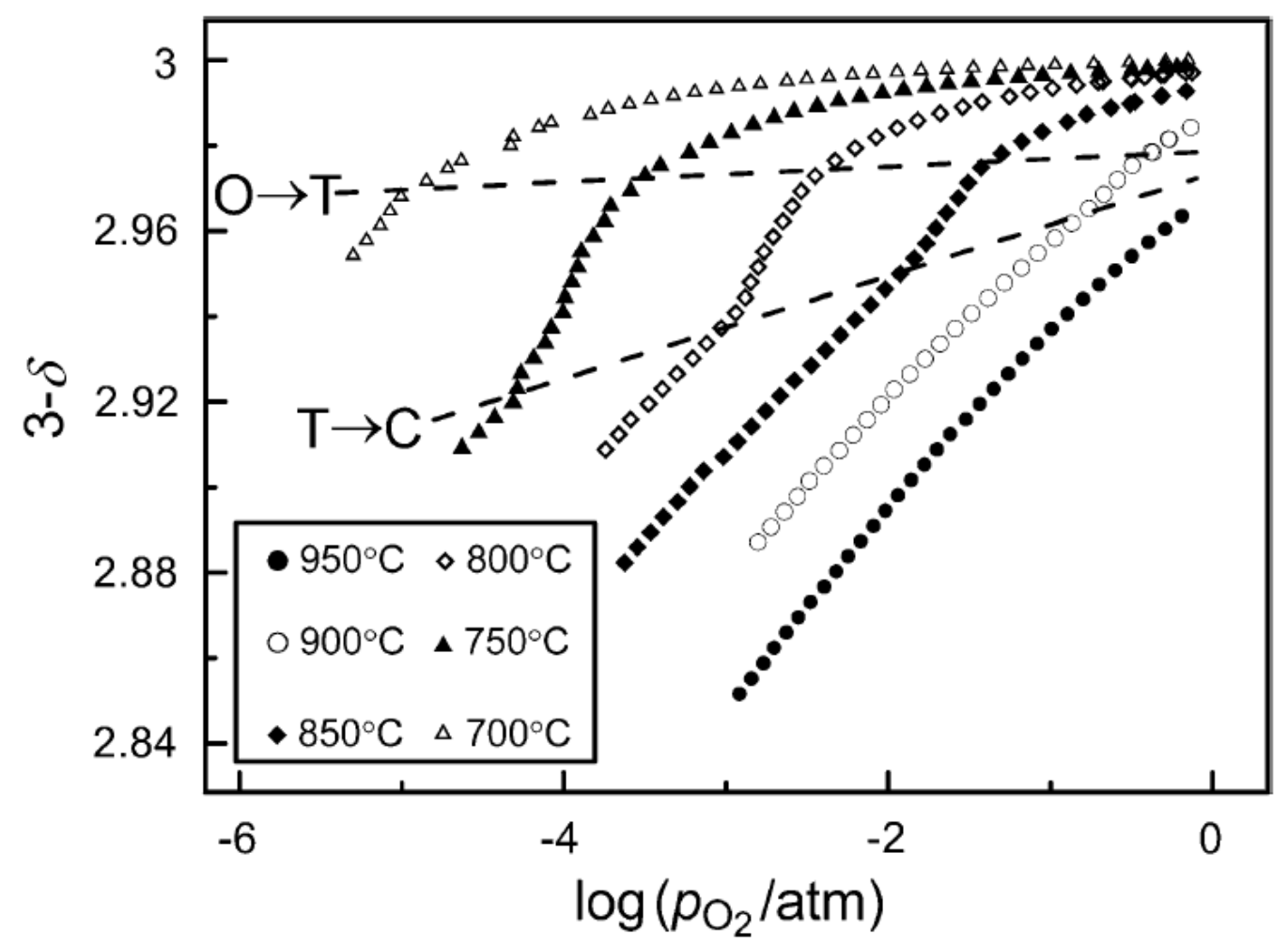

Figure 7: Equilibrium $\delta$ as function of $\mathrm{O}_{2}$ partial pressure for $\mathrm{CaMnO}_{3-\delta}$ at $700-950{ }^{\circ} \mathrm{C}$ measured by coulometric titration by Leonidova et. al [25]. 
Table 1: Summary of key characteristics for proposed oxygen carrier materials.

\begin{tabular}{|c|c|c|c|c|}
\hline Reaction & $\begin{array}{c}\mathbf{R}_{0} \\
\text { (wt\%) }\end{array}$ & $\begin{array}{c}\Delta \mathrm{H} \\
\left(\mathrm{kJ} / \mathrm{mol} \mathrm{O}_{2}\right)\end{array}$ & $\begin{array}{c}\mathrm{T}_{\text {eq,p02=5\% }} \\
\left({ }^{\circ} \mathrm{C}\right)\end{array}$ & $\begin{array}{c}\mathrm{T}_{\text {eq,pO2=21\% }} \\
\left({ }^{\circ} \mathrm{C}\right)\end{array}$ \\
\hline $4 \mathrm{CuO} \leftrightarrow 2 \mathrm{Cu}_{2} \mathrm{O}+\mathrm{O}_{2}$ & 10.06 & 261 & 959 & 1032 \\
\hline $6 \mathrm{Mn}_{2} \mathrm{O}_{3} \leftrightarrow 4 \mathrm{Mn}_{3} \mathrm{O} 4+\mathrm{O}_{2}$ & 3.38 & 195 & 796 & 871 \\
\hline $2 \mathrm{Co}_{3} \mathrm{O}_{4} \leftrightarrow 6 \mathrm{CoO}+\mathrm{O}_{2}$ & 6.64 & 408 & 854 & 893 \\
\hline $6\left(\mathrm{Mn}_{0.8} \mathrm{Fe}_{0.2}\right)_{2} \mathrm{O}_{3} \leftrightarrow 4\left(\mathrm{Mn}_{0.8} \mathrm{Fe}_{0.2}\right)_{3} \mathrm{O}_{4}+\mathrm{O}_{2}$ & 3.37 & 254 & & $\approx 965$ \\
\hline $6\left(\mathrm{Mn}_{0.5} \mathrm{Fe}_{0.5}\right)_{2} \mathrm{O}_{3} \leftrightarrow 4\left(\mathrm{Mn}_{0.5} \mathrm{Fe}_{0.5}\right)_{3} \mathrm{O}_{4}+\mathrm{O}_{2}$ & 3.36 & 344 & & $\approx 1005$ \\
\hline$(2 / 3) \mathrm{Mn}_{7} \mathrm{SiO}_{12}+4 \mathrm{SiO}_{2} \leftrightarrow(14 / 3) \mathrm{MnSiO}_{3}+\mathrm{O}_{2}$ & 4.15 & 315 & & $\approx 1050$ \\
\hline$(10 / 3) \mathrm{MnSiO}_{3}+(2 / 3) \mathrm{Mn}_{7} \mathrm{SiO}_{12} \leftrightarrow 4 \mathrm{Mn}_{2} \mathrm{SiO}_{4}+\mathrm{O}_{2}$ & 3.81 & 010 & & 1100 \\
\hline $25 \mathrm{CaMnO}_{2.92} \leftrightarrow 25 \mathrm{CaMnO}_{2.84}+\mathrm{O}_{2}$ & 0.90 & & & na \\
\hline $5 \mathrm{CaMnO}_{2.92} \leftrightarrow 5 \mathrm{CaMnO}_{2.52}+\mathrm{O}_{2}$ & & & & na \\
\hline $6 \mathrm{NiMn}_{2} \mathrm{O}_{4} \leftrightarrow 6 \mathrm{NiO}+4 \mathrm{Mn}_{3} \mathrm{O}_{4}+\mathrm{O}_{2}$ & & & $<<907$ & $\approx 907[26]$ \\
\hline $3 \mathrm{CuMn}{ }_{2} \mathrm{O}_{4} \leftrightarrow 3 \mathrm{CuMnO}_{2}+\mathrm{Mn}_{3} \mathrm{O}_{4}+\mathrm{O}_{2}$ & 49 & 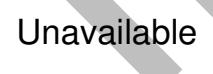 & $<<990$ & $\approx 990[29]$ \\
\hline $4 \mathrm{Mg}_{2} \mathrm{MnO}_{4} \leftrightarrow 2 \mathrm{MgMn}_{2} \mathrm{O}_{4}+6 \mathrm{MgO}+\mathrm{O}_{2}$ & & Unavailable & na & na \\
\hline $6 \mathrm{MgMn}_{2} \mathrm{O}_{4} \leftrightarrow 4 \mathrm{Mn}_{3} \mathrm{O}_{4}+6 \mathrm{MgO}+\mathrm{O}_{2}$ & 2.69 & Unavailable & na & na \\
\hline
\end{tabular}

